http://journals.ums.ac.id/index.php/ijolae

\title{
The Involvement In Tunas Niaga Activities and The Entrepreneurial Attitude Among Secondary Schools
}

\author{
Yap Kwee Leng1, Nor Aishah Buang ${ }^{2}$ \\ ${ }^{1,2}$ Faculty of Education, National University of Malaysia
}

DOI: $10.23917 /$ ijolae.v1i1.7288

Accepted: December $08^{\text {th }}, 2018$. Approved: January $17^{\text {th }}, 2019$. Published: February $15^{\text {th }}, 2019$.

\begin{abstract}
The purpose of this study is to identify the involvement in Tunas Niaga activities and the entrepreneurial attitude among secondary school. The involvement of entrepreneurial activity among students is an important component of forming entrepreneurial attitudes. However, entrepreneurial activity is less favored by high school students. Most high school students perceive entrepreneurship, tediousness and do not guarantee future lives during economic problems. Lacking the problem, a study was conducted to examine the level of involvement of entrepreneurial activity and entrepreneurial behavior. The study used survey method with questionnaire as the first instrument. The instruments is adapted from Khalina Khalid (1991) to construct the basic information of entrepreneurship activities as well as the construct of entrepreneurial attitude adapted from Ravi and Aishah Buang's instrument (2015) psychometric index of entrepreneurship. The sample of the study consists of 30 secondary school students taken randomly involving entrepreneurship activities such as Tunas Niaga.The results of the analysis of entrepreneurial entrepreneurship activity confirmed two constructs involving entrepreneurial activity with Cronbach Alpha's reliability and reliability value of .714. The dimensions of entrepreneurship showed that Cronbach Alpha .900. The min test results show the level of involvement of moderate entrepreneurship activities. Entrepreneurship attitude among respondents shows positive towards entrepreneurship activity.
\end{abstract}

Keywords: entrepreneurial activities, attitudes, secondary student

Corresponding Author:

Yap Kwee Leng, Faculty Pendidikan National University of Malaysia, Malaysia

Email: nisteryap8776@yahoo.com

\section{Introduction}

The entrepreneurship education is the

main source in order to produce a skillful main power, capable to develop innovation and technology in entrepreneurship as one of the strategies through a long term planning (Rangka Rancangan Jangka Panjang) (Norita, 2013). So, in the term of entrepreneurship education, it is very important to supply our students in the chances and potentional to choose entrepreneurship as their career. The purpose for entrepreneurship education is to develop the skills among students so that they can be more creative, initiative and wise to make a decision (Norita,
2013). Through entrepreneurship education, it also train a person to get ready for determining all the chances around him or her and grab them all so that it can be implement in everyday life as a form of economic activities. Besides, this also train a person to be sensitive with all the changes and the uncertainty (Nik Hairi Omar, 2012). The entrepreneurship education in secondary school also was been implement by two forms. The first form is in an accademic form and second form is in a co-curriculum form.

In the terms of academic, a part of the entrepreneurship principles had been thought 
starting from form 1 until form 6 so that this will able to spark a little bit interest among students in this field using a formal form of education. Through a formal education, the students can get into an awareness and also nurture the deep interest in the field of entrepreneurship (Zaifurin, 2016).

Furthermore, besides through a formal education, this entrepreneurship education also can be nurtured in a form of cocuriculum form such as involving in Tunas Niaga which is in form of entrepreneurship based activities. The purpose for having this type of activities is to enhance the entrepreneurship education not in the form of theories only but to expose students to practise them (hands-on) (Norita, 2013). Students also can be able to practise what they have learnt in class by implement them in a real form of business activities so that they can gain more new experiences from there.

Tunas Niaga activity can nurture culture and entrepreneurship values among secondary students as it is the main objective itself. This activity is a form of entrepreneurship and business to enhance the skill and knowledge in how to start and running an effective business. The involment in this activity of Tunas Niaga will be a platform for students to learn about entrepreneurship better and also generate a lot of meaningful experiences for them. Tunas Niaga also encourage students to involve in entrepreneurship voluntarily.

An entrepreneur does not has any spesific personalities or they born to be like that but there are the other factors and it can be trained (Zaidatol Akmaliah 1998, Halimah 2010). Beside that, Tunas Niaga activities can produce a resilient, competitive and viable entrepreneur and in the same time can enhance his or her abilities and knowledgeable to start and run business properly as the experiences is there (Perbadanan Kemajuan Negeri Sembilan, 2017).
The involvement in entrepreneurship activities is one step for culturing the value of entrepreneurship among school students. There are some funds that specially allocated for this in the annual school's budjet. Based on the annual report from the unit of entrepreneur develeopment, the number of Tunas Niaga members which consists of secondary school student is 21850 since 1998 until 2017. This number had been increased every year but sadly the objective to produce a students who has entrepreneurship characteristics is still low (Baharu, 2013). Wan Mohd Zaifurin (2015) also in his study reported that most students who had been involved any entrepreneurship activities such as Tunas Niaga also still depend on public or private sectors for their career. His datas stated that the number of entrepreneur in a group for age 15 to 34 years old are still low which is $39.3 \%$ in year 2015 .

The attitude of entrepreneurship also an important component that influences students to involve themselves in entrepreneural activities. Attitude will potray how ready a person is and a trust regarding an issue. So, author will focus on the attitude aspect that related with motivation, interest and confidence (Baharu, 2013). Beside that, entrepreneurship motivation also pushing students towards a positive thinking in involving entrepreneurship activities. Based on GEM Antarabangsa 2018 reports, Malaysia is on sixth from 60 countries in the motivational indexs where Malaysian entrepreneur choosed to grab chances based on the entrepreneurship motivation and not to start a necessity based business. Almost studies on entrepreneurship regarding attitude, thinking and behavior in interest among students on how they choose this field are focused based on undergraduate or polytechnic students. In additon, studies on the secondary school students are still very limited about attitude, thinking and behavior in entrepreneurship. So, a pilot study has to be carried out so that 
resercher can know about the involvement of secondary students in Tunas Niaga.

The previous studies showed that there are a slightly difference between the attitude orientation in entrepreneurship among Bumiputera Muslim youth because of their rate of formal education and they were always got the entrepreneurship training but however there is no significant difference based on the experience in business (Buerah, 2015). So, for the next study, it will be on the other factors such as entrepreneurship training programme and having experience in doing business in family members (Buerah, 2015). Entrepreneurship programme is a right predictor for measuring interest and student behavior towards entrepreneurship rather than demograph, personality and the other situation factors (Fayolle et al, 2006; Schout dan Harkema, 2010 dan Norfadhilah, 2015). So, it is important to study the rate of their entrepreneurship attitude by involvement in entrepreneurship activities among the secondary school students. The aim of this study is to determine this attitude towards their involement in entrepreneurship activities such Tunas Niaga among secondary school students.

The involvement in entrepreneurship activities is an important component for shaping the attitude towards entrepreneurship among students. This type of activity was introduced in school in order to change the student attitude towards entrepreneurship. Thus, the changes of student attitude towards entrepreneurship itself have their own barrier among themselves. They are left behind in the business knowledge itself and also lack of experience in running their own business. Most of the secondary school students have a bad perception towards entrepreneurship. They thought that entrepreneurship is tiring and do not guarantee a good future during the economic crisis (Zaifurin, 2016). Based on that problem, one study was conducted in order to determine the rate of involement in Tunas Niaga activities and also to study the entrepreneurship attitude. So, the objectives for this study are:

1. To determine the rate of involement in Tunas Niaga activities among secondary school students.

2. To study the min value of entrepreneurship attitude among secondary school students.

\section{The Involement in Tunas Niaga activities}

Entrepreneurship education that had been implemented in secondary school is aimed to nurture the interest and increase the knowledge about entrepreneurship among students. One of the activities that had been done in school is Tunas Niaga. Tunas Niaga activities are the form of entrepreneurship based activities. The students who involve in this activities will be able to increase their experiences in business for nine month period and also managing the activities organized by Tunas Niaga. All the activities in Tunas Niaga not only as a complement aspect in curiculum but also exposes the young generation about the entrepreneurship world (Ura et al, 2010). The involement of this young generation in entrepreneurship will increase the job vacancies to the citizens and also will be able to change the wage earner mentality among citizens (Nurfadhilah dan Halimah, 2010)

\section{Attitude Towards Entrepreneurship}

Attitude plays an inportant role that is able to spark behavior or attitude in entrepreneurship and also will be able to determine the success in this field soon (Krueger et al., 2000 and Baharu, 2013). Attitude refers to the overall assessment towards something based on a set of trust atribute which contains "way" and "degree" meaning. Way refers to likeness or dislikeness which potrays an adjective towards something (Fishbein and Ajzen, 1975; Hisyamuddin Hassan, 2010). Then, degree refers to a rate of likeness or dislikeness towards something 
which relate to object, idea and conditon. Attitude also can be a mental and nerves willingness that arranged according to experiences and can influences the individual responses towards the involvement in entrepreneurship. According to Fishbein dan Ajzen (1980) they said that an individual can become determined to do something if he or she has a positive attitude towards that perticular situation (Baharu 2013). The result from this study shows that secondary school students have a medium attitude towards entrepreneurship and positive towards involement in Tunas Niaga activities.

\section{Method}

This pilot study is conducted in a quantitative research. It used survey methodology with questionnaire as its study's instrument. The questionnaire forms have been used to collect datas in order to explain the demographic characteristics of respondent and explain the variables of this study toward the involvement in Tunas Niaga activities then the entrepreneurship attitude among secondary school students. The total respondents is 30 from the memberes of Tunas Niaga club among the secondary schools in Seremban's district. This amount of respondent is enough as Cooper dan Schindler dan Faizal (2014) said that the number of respondent that is suitable in a pilot study are from 25 until 100 respondents. While Johanson; Brooks dan Faizal (2014) suggested that the minimum number is 30 respondents for a pilot study and for creating the scale.

The sampling used in this study is a purposive sampling by choosing respondents who are the members of Tunas Niaga club in those school. So, samples for students who have experiences career is needed to comfirm all the items used to measure the rate of involvement in Tunas Niaga activities with entrepreneurship attitude. Thoses 30 questionnaire have been returned with complete answers. This all questionnaire used in analysing this pilot study before a real study will be conducted.

This data's analysis on the involvement in Tunas Niaga activities involved frequency, percentage, min score and standard deviation. The min value was been intrepreted according the scale from Bahagian Perancangan dan Penyelidikan Dasar pendidikan(2006) which is the score value 1.0-1.8 very low, 1.9-2.6 low, 2.7-3.4 medium, 3.5-4.2 high and 4.3-5.0 very high (Pallant 2010).

\section{A. Research Instruments}

This study involved a measurement instrument which is a process to determine the rate and value for variables that been studied. This instrument had been choosed because it is manageable and trustworthiness. This means that the questionnaire forms can be managed by author itself by meeting session in course, tutorial or seminar. Author also can distribute the questionnaire forms directly to respondents and explain to them about this study.

The questionnaire instrument contained four sections. This four sections are Section A: Respondent Background, Section B: The Principles of entrepreneurship, Section C: The Rate of Involvement in Tunas Niaga Activities and finally Section D: Attitude Towards Entrepreneurship. Section A has 9 items, 7 items for Section B, 25 items for Section C and 15 items for Section D in order to measure the result.

All these instruments built based on the adjustment and renavation from study carried by Khalina Khalid (1991) and attitude contructs in entrepreneurship from NorAishah Buang (2011) study. Then, all the items in that questionnaire are in a closed form and answerd by choosing from 1 unit to 4 in Likert Scale. This type of scale had been 
choosen because it is easy to be conducted by a large amont of respondents, help respondents to focus on the subject and make the process in making tables easily for analysing datas (Deobold, 1999). For the involvement in Tunas Niaga activities and entrepreneurship attitude, author used Likert Scale 4 for respondent to choose by stating the rate of every factors. However, the questionnaire by using Likert Scale 5 has a low rustworthiness and validity because the items in the questionnaire asked reponsents to give the same pattern of answers (Chua 2012). So, author used Likert Scale 4 in order to measure the respondents given by all the respondents.

The analysis of trustworthiness using Alpha Cronbach with the coefficient $\alpha$ used to determine the inner cosistency, accuracy and the stability of the measurement tool in order to get a realiable items (Othman Talib 2015). The coefficient used to try the validity of the items based on the rate of involvement in entrepreneurship activities with the attitude construct among the secondary school students.

The value of trustworthiness for a good measurement tool is between $0.70-0.80$ and the coefficient $\mathrm{a} \geq 0.90$ is very good (Kaplan dan Saccuzzo; Atiqah 2016). As the trustworthiness coefficient in the item of involvement in Tunas Niaga activitis obtained is .729 while the item of entrepreneurship attitude obtained is .896 . Based on the that value, both items are in a good measurement which is between $0,70-$ 0.80 .

\section{B. Collecting and Analysing Data}

Before the questionnaire was distributed, author gathered all respondents in order to give them some explaination about this study and how they may answer all the questions in the questionnaire. Author explained them that all the answers are confidential and all the datas from this questionnaire will be used only to determine the objectives of this study. Beside that, any questions regarding the items will be explained by author. Respondents also was been given 45 minutes to answer the questionnaire. After finished, all the answers will be examined by author in order to ensure that there is no question left unanswered.

\section{The Respondents' Profiles}

Table 1 shows profiles for all the respondents in this study. By analysis, there are also female students who involved in Tunas Niaga which is 16 students $(53.3 \%)$ rather than male students with 14 students (46.7\%). The Malay students coverd 24 students $(80 \%)$, chinese 1 student $(3,3 \%)$ while Indian are 5 students (16.7\%). From science stream, 9 students $(30 \%)$ and art stream 21 students (70\%). Then, the respondent who had experiences in entrepreneurship are 30 students (100\%). While the number of respondents who involved in Tunas niaga less than one year are 17 students $(56.7 \%)$, one year are 2 students $(6.7 \%), 2$ years are 3 students $(10 \%), 4$ years are 5 students $(16.7 \%)$ and 6 years are 3 students $(10.0 \%)$. Next, their fathers' occupations as businessman with 6 students (20\%), selfworking 3 students $(10 \%)$ and government worker 8 students $(26,7 \%)$, private sector are 6 students $(20 \%)$ and the others are 7 students (23.3\%). Furthermore, their mothers' occupation as house wifes are 10 students (33.3\%), businesswoman 6 students $(20 \%)$ and government sector are 7 students $(23.3 \%)$. While the respondents' mom who are selfworkers beside doing business are 2 students $(6.7 \%)$ and who work in private sector is 1 student only (3.3\%). 
Table 1. Respondents' Profile

\begin{tabular}{|c|c|c|c|}
\hline Profile & Category & Frequency & Percentage (\%) \\
\hline Gender & $\begin{array}{l}\text { Male } \\
\text { Female }\end{array}$ & $\begin{array}{l}14 \\
16\end{array}$ & $\begin{array}{l}46.7 \\
53.3\end{array}$ \\
\hline Race & $\begin{array}{l}\text { Malay } \\
\text { Chinese } \\
\text { Indian }\end{array}$ & $\begin{array}{l}24 \\
1 \\
5\end{array}$ & $\begin{array}{l}80 \\
3.3 \\
16.7\end{array}$ \\
\hline Stream & $\begin{array}{l}\text { Science } \\
\text { Art }\end{array}$ & $\begin{array}{l}9 \\
21\end{array}$ & $\begin{array}{l}30 \\
70\end{array}$ \\
\hline $\begin{array}{l}\text { Experience in taking entrepre- } \\
\text { neurship subject }\end{array}$ & $\begin{array}{l}\text { Yes } \\
\text { No }\end{array}$ & $\begin{array}{l}14 \\
16\end{array}$ & $\begin{array}{l}46.7 \\
53.3\end{array}$ \\
\hline $\begin{array}{l}\text { Experience in joinning entrepre- } \\
\text { neurship activities }\end{array}$ & $\begin{array}{l}\text { Yes } \\
\text { No }\end{array}$ & $\begin{array}{l}30 \\
-\end{array}$ & $\begin{array}{l}100.0 \\
-\end{array}$ \\
\hline $\begin{array}{l}\text { How long be a member of Tunas } \\
\text { Niaga }\end{array}$ & $\begin{array}{l}\text { Less than } 1 \text { year } \\
1 \text { year } \\
2 \text { years } \\
4 \text { years } \\
6 \text { years }\end{array}$ & $\begin{array}{l}17 \\
2 \\
3 \\
5 \\
3\end{array}$ & $\begin{array}{l}56.7 \\
6.7 \\
10.0 \\
16.7 \\
10.0\end{array}$ \\
\hline Fathers' Occupation & $\begin{array}{l}\text { Businessman } \\
\text { Selfworking } \\
\text { Goverment Staff } \\
\text { Private Sector Staff } \\
\text { The others }\end{array}$ & $\begin{array}{l}6 \\
3 \\
8 \\
6 \\
7\end{array}$ & $\begin{array}{l}20.0 \\
10.0 \\
26.7 \\
20.0 \\
23.3\end{array}$ \\
\hline Mothers' Occupation & $\begin{array}{l}\text { Doing Bussiness } \\
\text { Selfworking } \\
\text { Goverment Staff } \\
\text { Private Sector Staff } \\
\text { Housewife } \\
\text { The others }\end{array}$ & $\begin{array}{l}6 \\
2 \\
7 \\
1 \\
10 \\
4\end{array}$ & $\begin{array}{l}20.0 \\
6.7 \\
23.3 \\
3.3 \\
33.3 \\
13.3 \\
\end{array}$ \\
\hline
\end{tabular}

3. Results and Discussion

A. Objective 1: Determine the Rate of Involvement in Tunas Niaga Entrepreneurship Activities

The rate of involvement in Tunas Niaga entrepreneurship activities was measured by using the perception constructs in Tunas Niaga itself. Frequency analysis and percentage for every items as shows in Table 2 and Table 3. The involvement had been measured based on two subcontructs which are the students' perception about Tunas Niaga meeting and the students' perception about the involvement of students in managing the entrepreneurship activities. Table 4 shows the overall analysis for the constructs about the attitude in entrepreneurship.
Table 2 shows the analysis for the subconstruct in the students' perception about their involvement in Tunas Niaga meeting. The analysis stated that three items recorded the percentage of agreeness more than $70 \%$. Item $\mathrm{C} 1$ recorded the percentage of agreeness with 23 responents $(76.7 \%)$ for strongly agree and agree always be the customer at Tunas Niaga. Item C2 recorded the percentage of agreeness with 23 respondents $(76.7 \%)$ strongly agree and agree to always strive so that they can be choosen as one of the members of Tunas Niaga. Item $\mathrm{C} 4$ recorded the percentage of agreeness are 21 respondents $(70 \%)$ are strongly agree and agree to spend their time to clean and arrange the things in Tunas Niaga. Finally, item C5 shows that 27 respondents are strongly disagree and 
disagree that Tunas Niaga is not a suitable place for buying bacis things.

Then, for item $\mathrm{C} 7$ shows 22 respondents $(83.4 \%)$ are strongly agree and agree that they dislike to join the meeting organized by Tunas Niaga. But, there are 8 respondents
(26.6\%) strongly disagree and disagree about item C7. For item C8 recorded that the lowest percentage of agreeness are 2 respondents $(6.7 \%)$ because both respondents thought that the schedule for Tunas Niaga is burdening students.

Table 2. Perception About the Involvement of Students in Tunas Niaga Annual Meeting

\begin{tabular}{|c|c|c|c|}
\hline \multirow{2}{*}{ Item } & \multirow{2}{*}{$\begin{array}{l}\text { Construct of the Student Involvement in Entre- } \\
\text { preneurship Activities }\end{array}$} & \multicolumn{2}{|c|}{ Frequancy and Percentage } \\
\hline & & STS-TS & S-SS \\
\hline $\mathrm{C} 1$ & Always be Tunas Niaga customer. & $\begin{array}{c}7 \\
(23.3 \%)\end{array}$ & $\begin{array}{c}23 \\
(76.7 \%)\end{array}$ \\
\hline $\mathrm{C} 2$ & $\begin{array}{l}\text { In every annual meeting, I try to make me elected as } \\
\text { a member of Tunas Niaga. }\end{array}$ & $\begin{array}{c}7 \\
(23.3 \%)\end{array}$ & $\begin{array}{c}23 \\
(76.7 \%)\end{array}$ \\
\hline $\mathrm{C} 3$ & I had handle the annual meeting of Tunas Niaga. & $\begin{array}{c}24 \\
(80 \%)\end{array}$ & $\begin{array}{c}6 \\
(20 \%)\end{array}$ \\
\hline $\mathrm{C} 4$ & $\begin{array}{l}\text { I always spending by time to clean and arrange } \\
\text { things in Tunas Niaga. }\end{array}$ & $\begin{array}{l}9 \\
(30 \%)\end{array}$ & $\begin{array}{c}21 \\
(70 \%)\end{array}$ \\
\hline $\mathrm{C} 5$ & $\begin{array}{l}\text { Tunas Niaga is not a choosen place for getting my } \\
\text { needed items. }\end{array}$ & $\begin{array}{c}27 \\
(90 \%)\end{array}$ & $\begin{array}{c}3 \\
(10 \%)\end{array}$ \\
\hline C6 & Managing Tunas Niaga is disturbing my studies. & $\begin{array}{c}26 \\
(86.6 \%)\end{array}$ & $\begin{array}{c}4 \\
(13.4 \%)\end{array}$ \\
\hline $\mathrm{C} 7$ & $\begin{array}{l}\text { I did like to involve myself in the annual meeting } \\
\text { organized by Tunas Niaga. }\end{array}$ & $\begin{array}{c}8 \\
(26.6 \%)\end{array}$ & $\begin{array}{c}22 \\
(83.4 \%)\end{array}$ \\
\hline $\mathrm{C} 8$ & Schedule in Tunas Niaga burdening myself. & $\begin{array}{c}28 \\
(93.3 \%)\end{array}$ & $\begin{array}{c}2 \\
(6.7 \%)\end{array}$ \\
\hline C9 & $\begin{array}{l}\text { Attending Tunas Niaga annual meeting is wasting } \\
\text { my time. }\end{array}$ & $\begin{array}{c}25 \\
(83.3 \%)\end{array}$ & $\begin{array}{c}5 \\
(16.7 \%)\end{array}$ \\
\hline
\end{tabular}

However, item C6 shows that 26 repondents $(86.6 \%)$ strongly disagree and disagree about the activities in Tunas Niaga are disturbing their studies. While item C9 shows that 25 respondents $(83.3 \%)$ are strongly disagree and disagree about the attendance for the Annual Meeting of Tunas Niaga is wasting their time.Overall, the respondents showed a high percentage of agreeness that they dislike to handle the meeting in order to develop the entrepreneurship activities in school. However, students still feel motivated to attend the Annual Meeting and not give a bad perception about Tunas Niaga by stating it is disturbing their studies.

Perception in Students' Involvement for Managing Activities inTunas Niaga.
Table 3 shows the perception in students' involvement for managing activities in Tunas Niaga. Analysis shows that $\mathrm{C} 22$ recorded the highest percentage of agreeness with 28 respondents (93.3\%) about Tunas Niaga is benificial. However, 2 respondents $(6.7 \%)$ both are strongly disagree and disagree about this statement. Item $\mathrm{C} 21$ recorded the second highest persentage of agreeness with 27 respondents (90\%) strongly agree and agree about one of the way to develop Tunas Niaga is by its customers. However, there are 3 respondents $(10 \%)$ who are strongly disagree and disagree about this statement. In Addition, C14 got 26 respondents $(86.7 \%)$ who are strongly agree that by visiting the other Tunas Niaga will help to develop Tunas 
Niaga in school but 4 respondents (13.3\%) are strongly disagree and disagree about this statement.

For item C10, the percentage for agreeness are 22 respondents $(73.4 \%)$ strongly agree and agree in involving actively in the activities organized by Tunas Niaga. Item $\mathrm{C} 11$ then shows the percentage of agreeness are 4 respondents (13.3\%) strongly agree and agree that they are managing Tunas.

Table 3. The Students' Perception About Their Involvement in Tunas Niaga Activities

\begin{tabular}{|c|c|c|c|}
\hline $\mathrm{C} 10$ & $\begin{array}{l}\text { I alway involve actively in the activities organi- } \\
\text { zed by Tunas Niaga. }\end{array}$ & $\begin{array}{c}8 \\
(26.6 \%)\end{array}$ & $\begin{array}{c}22 \\
(73.4 \%)\end{array}$ \\
\hline $\mathrm{C} 11$ & I manage my Tunas Niaga shop properly. & $\begin{array}{c}26 \\
(86.7 \%)\end{array}$ & $\begin{array}{c}4 \\
(13.3 \%)\end{array}$ \\
\hline $\mathrm{C} 12$ & $\begin{array}{l}\text { I alway give suggestions in annual meeting for } \\
\text { my school Tunas Niaga. }\end{array}$ & $\begin{array}{c}11 \\
(36.6 \%)\end{array}$ & $\begin{array}{c}19 \\
(63.3 \%)\end{array}$ \\
\hline $\mathrm{C} 13$ & I like to buy thing at Tunas Niaga. & $\begin{array}{c}24 \\
(80 \%)\end{array}$ & $\begin{array}{c}6 \\
(20 \%)\end{array}$ \\
\hline $\mathrm{C} 14$ & $\begin{array}{l}\text { Visiting the other Tunas Niaga can be helping } \\
\text { to develope Tunas Niaga. }\end{array}$ & $\begin{array}{c}4 \\
(13.3 \%)\end{array}$ & $\begin{array}{c}26 \\
(86.7 \%)\end{array}$ \\
\hline $\mathrm{C} 15$ & $\begin{array}{l}\text { I alway help Tunas Niaga teachers in managing } \\
\text { Tunas Niaga tasks. }\end{array}$ & $\begin{array}{c}11 \\
(36.6 \%)\end{array}$ & $\begin{array}{c}19 \\
(63.4 \%)\end{array}$ \\
\hline $\mathrm{C} 16$ & $\begin{array}{l}\text { I alway know every activities organized by } \\
\text { Tunas Niaga. }\end{array}$ & $\begin{array}{l}9 \\
(30 \%)\end{array}$ & $\begin{array}{c}21 \\
(70 \%)\end{array}$ \\
\hline $\mathrm{C} 17$ & Involving in Tunas Niaga is wating my time. & $\begin{array}{l}29 \\
(96.7 \%)\end{array}$ & $\begin{array}{c}1 \\
(3.3 \%)\end{array}$ \\
\hline $\mathrm{C} 18$ & $\begin{array}{l}\text { Ensuring Tunas Niaga runs smoothly and pro- } \\
\text { perly is not my duty. }\end{array}$ & $\begin{array}{c}28 \\
(93.3 \%)\end{array}$ & $\begin{array}{c}2 \\
(6.7 \%)\end{array}$ \\
\hline $\mathrm{C} 19$ & $\begin{array}{l}\text { I alway know every activities organized by } \\
\text { Tunas Niaga. }\end{array}$ & $\begin{array}{l}9 \\
(30 \%)\end{array}$ & $\begin{array}{c}21 \\
(70 \%)\end{array}$ \\
\hline $\mathrm{C} 20$ & $\begin{array}{l}\text { I alway attend the my school Tunas NIaga an- } \\
\text { nual meeting. }\end{array}$ & $\begin{array}{l}11 \\
(36.7 \%)\end{array}$ & $\begin{array}{c}19 \\
(63.3 \%)\end{array}$ \\
\hline $\mathrm{C} 21$ & $\begin{array}{l}\text { One of the ways to develop Tunas Niaga is by } \\
\text { its customers. }\end{array}$ & $\begin{array}{l}3 \\
(10 \%)\end{array}$ & $\begin{array}{c}27 \\
(90 \%)\end{array}$ \\
\hline $\mathrm{C} 22$ & $\begin{array}{l}\text { Tunas Niaga activities in my school are very } \\
\text { benificial. }\end{array}$ & $\begin{array}{l}2 \\
(6.7 \%)\end{array}$ & $\begin{array}{c}28 \\
(93.3 \%)\end{array}$ \\
\hline $\mathrm{C} 23$ & $\begin{array}{l}\text { I did like to give my opinions to develop my } \\
\text { Tunas Niaga. }\end{array}$ & $\begin{array}{c}26 \\
(86.7 \%)\end{array}$ & $\begin{array}{c}4 \\
(13.3 \%)\end{array}$ \\
\hline $\mathrm{C} 24$ & $\begin{array}{l}\text { I rarely getting know about the developement of } \\
\text { my Tunas Niaga. }\end{array}$ & $\begin{array}{c}26 \\
(86.7 \%)\end{array}$ & $\begin{array}{c}4 \\
(13.3 \%)\end{array}$ \\
\hline $\mathrm{C} 25$ & $\begin{array}{l}\text { I had attended an induction course organized by } \\
\text { my Tunas Niaga. }\end{array}$ & $\begin{array}{c}13 \\
(43.3 \%)\end{array}$ & $\begin{array}{c}17 \\
(56.6 \%)\end{array}$ \\
\hline
\end{tabular}

Niaga shop properly. While 26 shows 19 respondents (63.3\%) strongly respondents $(86.7 \%)$ strongly disagree and agree and agree that they always give disagree about this statement. Item $\mathrm{C} 12$ suggestions in Tunas Niaga meeting. 
However, 11 respondents (36.6\%) strongly disagree and disagree that they always give suggestions in meeting. Item $\mathrm{C} 13$ then shows 6 respondents $(20 \%)$ are strongly agree and agree that they always buy items at Tunas Niaga but there are 24 respondents (80\%) how are strongly disagree and disagree about that statement. Although item $\mathrm{C} 17$ shows the lowest percentage with 1 respondent (3.3\%) strongly agree and agree that this activity in Tunas Niaga that Tunas Niaga is wasting their time. According to the finding, it shows that respondents were interested in involving themselves in Tunas Niaga activities.

For item $\mathrm{C} 18$, there are 2 respondents $(6.7 \%)$ strongly agree and agree that to make sure Tunas Niaga to run smoothly is not their duty. Thus, 28 respondents (93.3\%) strongly disagree and disagree about this item. Item C23 and C24 show the same percentage where both have 4 respondents (13.3\%) strongly agree and agree that I dislike to propose any oppinion to develop Tunas Niaga further and rarely to take care about the development of Tunas Niaga. However, 26 respondents $(86.7 \%)$ strongly disagree and disagree about the above statement. So, the result shows that respondents even are willing to contribute ideas and suggestions in order to develop Tunas Niaga. Overall, respondents had shown a high percentage of agreeness that they always involve actively in the activities organized by Tunas Niaga.

\section{B. Objective 2: Determine Min for Entrepreneurship Attitude}

Table 4. Entrepreneurship Attitude

\begin{tabular}{|c|c|c|c|}
\hline Item & Min & $\begin{array}{l}\text { Standart } \\
\text { Deviation }\end{array}$ & Rate \\
\hline 1. I feel very satisfied with my works. & 3.36 & .668 & Moderate \\
\hline 2. I never delayed the important thing to the other suitable time. & 3.23 & .626 & Moderate \\
\hline $\begin{array}{l}\text { 3. I belive that a strong desision is very important to ensure the } \\
\text { sucess in entrepreneurship activities. }\end{array}$ & 3.46 & .571 & Moderate \\
\hline $\begin{array}{l}\text { 4. I belive that it is very importan to analys self weakness about } \\
\text { important things. }\end{array}$ & 3.43 & .571 & Moderate \\
\hline $\begin{array}{l}\text { 5. I always sacrifice my private comfortness in order to get a better } \\
\text { chances. }\end{array}$ & 2.93 & 639 & Moderate \\
\hline $\begin{array}{l}\text { 6. I alway completing every works with all my struggle and pro- } \\
\text { perly to get what I target for. }\end{array}$ & 3.30 & .701 & Moderate \\
\hline $\begin{array}{l}\text { 7. I struggle do something and thoroughly to get the best drom my } \\
\text { job. }\end{array}$ & 3.30 & .702 & Moderate \\
\hline $\begin{array}{l}\text { 8. I feel proud when doing good things for the entrepreneurship } \\
\text { activites that have been organized. }\end{array}$ & 3.26 & .583 & Moderate \\
\hline $\begin{array}{l}\text { 9. I feel proud when seeing the achived results in the entrepre- } \\
\text { neurship activities from my own struggle. }\end{array}$ & 3.33 & .604 & Moderate \\
\hline $\begin{array}{l}\text { 10. I belive that it is better to think about the future rather to think } \\
\text { about acheivement. . }\end{array}$ & 3.36 & .718 & Moderate \\
\hline 11. I did the meaningful things when doing work every day. & 3.40 & .621 & Moderate \\
\hline 12. I feel satisfief after I had work hard to develop myself. & 3.43 & .568 & Moderate \\
\hline 13. I can get the satisfaction from my struggle that I have done. & 3.30 & .466 & Moderate \\
\hline 14. I alway work harder to make myself better in my field. & 3.30 & .651 & Moderate \\
\hline 15. I can make the chances that can be benificial for me. & 3.26 & .583 & Moderate \\
\hline Total Min & 3.31 & & Moderate \\
\hline
\end{tabular}

Table 4 shows the second objective which the min score for the entrepreneurship attitude among secondary school students. The result from statistic analysis shows that this attitude among respondents who involved in entrepreneurship avtivities is still medium with overall $\min$ score $=3.31$. Overall, this result shows that respondents still have a positive entrepreneurship attitude after involving themselves in Tunas Niaga 
among the secondary school students. The finding shows that that rate of involvement in entrepreneurship activities Tunas Niaga has a high percentage of agreeness which involves 22 respondent $(73.3 \%)$ are involving actively in Tunas Niaga.

Then, the study analysis also states that there are 28 respondent $(93.3 \%)$ who are agree that joining Tunas Niaga is very benificial. So, the min value for student entrepreneurship attitude in secondary school shows a positive moderate after joinning Tunas Niaga activtites.

Furthermore, this finding also cosistent to what Azmin (2012) got that the students who join entrepreneurship activities have a good entrepreneurship potential and characterictics such as attitude, thinking and behavior at a maximum point. So, this entrepreneurship attitude can be influenced by the involvement in entrepreneurship activities continuosly until they are really be in an entrepreneurship situation. Beside that, the entrepreneur personalities also can be shaped by the experiences and knowledge they gainned from Model Personaliti Masyarakat (Thomas Cochrau dan Eika Sachi 2011). This entrepreneurship attitude can be refer as a consideration or individual tendency to have, establish and run their business. Attitude also can be suppose as human behavior predictor (Dale H.Schunk 2004).

\section{Conclusion}

The consideration culture has to be started from school. At this stage, students have to be exposed to the principle and also entrepreneurship habits so that can generate their positive entrepreneurship attitude. Entrepreneur can be develop by giving them a good entrepreneurship trainning and also practic them in entrepreneurship activities. The will be teach, guide and support for capital and management. However all this things cannot be done if the students themselves did not grab this chances by involving themselve in entrepreneurship activities.

5. References

Armanurah Mohamad, Syahrina Abdullah. 2015. Transformasi pemikiran keusahawanan bagi dimensi mengenal peluang keusahawanan dalam kalangan OKU. Journal of Global business and Sosial Entrepreneurship.

Baharu Kemat Al-Haji dan Mohammed Zain Yusof. 2013. Sikap Keusahawanan dan hasrat Keusahawanan: Satu Penilaian Instrumen Mengkaji Kecenderungan Usahawan. Jurnal Personalia Pelajar.

Buerah Tunggak dan Zoolhilmi Ahmed. 2015. Pengaruh Faktor Latar Belakang terhadap Orientasi Sikap Keusahawanan dalam kalangan Usahawan Belia Bumiputera Muslim. Akademika.

Chua Yan Piaw. 2011. Kaedah Penyelidikan. Edisi ke-2. Malaysia: Mc Graw Hill. Coopersmith, S. $1967 . \quad$ Self-esteem Inventory (SEI). Palo Alto, CA: Consulting Psychologist Press.

Dale H. Schunk. 2004. Learnng Theories: An Educational Perspective. Pearson Merill Prentice Hall.

Eika Sachi. 2011. Aspirasi Keusahawanan. Akademika.

Faizal Amin Yunus. 2014. Instrumen Pemindahan Pembelajaran Berdasarkan Model Rasch: First Teknical and Vocational Education Seminar 2014.

Jabatan Perangkaan Malaysia. 2011. Buku Tahunan Perangkaan Malaysia 2010. Jabatan Perangkaan Malaysia.

Kerlinger, F.N. 1986. Statistical Analysis: An Interdisciplinary Introduction to Univariate and Multivariate Methods. 2nd Ed. NY: Radius Press.

Khalina Khalid. 1991. Peranan Koperasi Dalam Memupuk Budaya Keusahawanan Di Kalangan Anggotaanggotanya. Universiti Kebangsaan Malaysia. 
Laporan Tahunan Bahagian Pembangunan Usahawan 2017.Data diperolehi dari www.pknsbizpoint.com.

Nik Hairi Omar. 2012. Potensi Keusahawanan dan ciri-ciri keusahawanan dalam kalangan pelajar sekolah Menengah. Proceeding of the 2nd International Conference on Arts, Sosial Sciences Penang Malaysia.

Nurfadhilah Nasharudin \& Halimah Harun. 2010. Aspirasi kerjaya keusahawanan dalam kalangan pelajar Institusi Pengajian Tinggi Awam. Universiti Kebangsaan Malaysia. Jurnal Pendidikan Malaysia 35(1): 11-17.

Norita Deraman, Amanurah dan etc. 2010. Keusahawanan: Teori dan Praktis. McGraw Education.

Perbadanan Kemajuan Negeri Sembilan. 2018. Dipetik daripada www.pkns.gov.my

Ravi Nagarathanam. 2015. Hubungan sikap, Pemikiran dan Tingkah Laku Terhadap Keinginan Dalam Pemilihan Kerjaya Keusahawanan Dalam Kalangan Prasiswazah India Di Institut Pengajian Tinggi Sekitar Bangi. Universiti Kebangsaan Malaysia.
Rohaida Mohommad Dhalan dan Razaleigh Muhamat. 2014. Penilaian Kepada Koperasi Sekolah Dalam Membentuk Gaya Kepimpinan Pelajar. Jurnal AlHikmah 6:107-121. Universiti Kebangsaan Malaysia.

Wan Mohd Zaifurin Wang Nawang, Nor hayati Sa'at dan Sabri Ahmad etc. 2016. Kecenderungan Keusahawanan dalam kalangan Pelajar Sekolah Menengah di Negeri Terengganu. Jurnal Pendidikan Malaysia 41(1)8:87-98.

Zaidatol Akhmaliah Lope Pihie and Afsaneh Bagheri. 2011. Malay students' entrepreneur attitude and entrepreneurial efficacy in Vocational and Technical Secondary School of Malaysia. Universiti Putra Malaysia. Journal Pertanika Science Social and Humanity 19(2): 433-447.

Zaidatol Akmaliah Lope Pihie dan Hisyamuddin Hassan. 2010. Memperkasa Tekad Keusahawanan Pelajar. Universiti Putra Malaysia. Serdang. 